\title{
Clostridium perfringens Beta2 toxin forms highly cation-selective channels in lipid bilayers
}

\author{
Roland Benz ${ }^{1}\left[\right.$ ( $\cdot$ Claudio Piselli ${ }^{1} \cdot$ Cezarela Hoxha ${ }^{1,2} \cdot$ Cornelia Koy $^{3} \cdot$ Michael O. Glocker $^{3} \cdot$ Michel R. Popoff $^{2}$
}

Received: 9 April 2021 / Revised: 28 August 2021 / Accepted: 14 November 2021 / Published online: 2 December 2021

(c) The Author(s) 2021

\begin{abstract}
Clostridium perfringens is a potent producer of a variety of toxins. Well studied from these are five toxins (alpha, Beta (CPB), epsilon, iota and CPE) that are produced by seven toxinotype strains (A-G) of $C$. perfringens. Besides these toxins, C. perfringens produces also another toxin that causes necrotizing enterocolitis in piglets. This toxin termed consensus Beta2 toxin (cCPB2) has a molecular mass of 27,620 Da and shows only little homology to CPB and no one to the other toxins of $C$. perfringens. Its primary action on cells remained unknown to date. CCPB2 was heterogeneously expressed as fusion protein with GST in Escherichia coli and purified to homogeneity. Although cCPB2 does not exhibit the typical structure of beta-stranded pore-forming proteins and contains no indication for the presence of amphipathic alpha-helices we could demonstrate that CCPB2 is a pore-forming component with an extremely high activity in lipid bilayers. The channels have a single-channel conductance of about $700 \mathrm{pS}$ in $1 \mathrm{M} \mathrm{KCl}$ and are highly cation-selective as judged from selectivity measurements in the presence of salt gradients. The high cation selectivity is caused by the presence of net negative charges in or near the channel that allowed an estimate of the channel size being about $1.4 \mathrm{~nm}$ wide. Our measurements suggest that the primary effect of CCPB2 is the formation of cation-selective channels followed by necrotic enteritis in humans and animals. We searched in databases for homologs of cCPB2 and constructed a cladogram representing the phylogenetic relationship to the next relatives of $\mathrm{cCPB} 2$.
\end{abstract}

Keywords Pore-forming toxins · Consensus Clostridium perfringens Beta2 toxin (cCPB2) · Propidium iodide uptake · Channel formation $\cdot$ Cation-selectivity $\cdot$ Lipid bilayer membrane

\section{Introduction}

Clostridium perfringens consensus Beta2 toxin (cCPB2) has been first identified as the unique virulence factor of a $C$. perfringens strain isolated from a piglet neonatal necrotic enteritis (Gibert et al. 1997). cCPB2 shows a low amino acid sequence identity (less than 15\%) with C. perfringens Beta toxin (CPB) which is characteristic of $C$. perfringens types $\mathrm{B}$ and $\mathrm{C}$ and which is responsible for necrotic enteritis notably in young animals (Songer 2010; Uzal et al. 2010; Rood et al. 2018). C.

Roland Benz

roland.benz@mail.uni-wuerzburg.de

1 Department of Life Sciences and Chemistry, Jacobs University, Campus Ring 1, 28759 Bremen, Germany

2 Bacterial Toxins, Institut Pasteur, 28 Rue du Dr Roux, Paris, France

3 Proteome Center Rostock, University Medicine Rostock, 18059 Rostock, Germany perfringens harboring cCPB2 gene (ccpb2), CPB gene (cpb) alone, or both $c p b+c c p b 2$ were associated with necrotic enteritis in piglets, and strains containing $c c p b 2$ were also isolated from horses with typhlocolitis (Gibert et al. 1997). C. perfringens containing ccpb2 were further described from a wide range of animals including piglets, horses, calves, chickens, dogs, and from humans (Herholz et al. 1999; Garmory et al., 2000; Manteca et al. 2002; Bueschel et al. 2003; Waters et al. 2003; Allaart et al. 2012; Lebrun et al. 2007; Carman et al. 2008; Ferrarezi et al. 2008; van Asten et al. 2010; Hazlett et al. 2011; Chan et al. 2012; Goldstein et al. 2012; Farzan et al. 2013; Gohari et al. 2014; França et al. 2016; Park and Rafii, 2019). ccpb2 is localized on plasmid in C. perfringens and it is widespread among the $C$. perfringens strains (Gibert et al. 1997; Waters et al. 2003; Fisher et al. 2005; Harrison et al. 2005; Gurjar et al. 2010). Genetic investigations of $c p b 2$ in various $C$. perfringens strains from different origin showed a diversity of this toxin gene. ccpb2, is predominant in porcine isolates, whereas variants of $c p b 2$, called atypical $c p b 2$ 
(acpb2), are harbored by non-porcine isolates (Jost et al. 2005). aCPB2 from the different $C$. perfringens types differ from 1 to 14 amino acid positions. A frameshift in $a c p b 2$ gene in some $C$. perfringens strains results in the expression of a truncated CPB2 (Jost et al. 2005; Vilei et al. 2005). This might explain the absence of CPB2 effects in these strains. However, antibiotic treatment of $C$. perfringens with aminoglycosides such as gentamycin or streptomycin is able to induce a frameshifting and thus to allow the expression of $c p b 2$ as this has been demonstrated with $C$. perfringens strains from equine origin. Indeed, antibiotic treatment in horse predisposes to severe and fatal typhlocolitis with $C$. perfringens cpb2 strains (Vilei et al. 2005). Albeit associations of $C$. perfringens harboring $c p b 2$ with intestinal diseases have been described, the role of cCPB2 and $\mathrm{aCPB} 2$ in pathogenesis remains unclear (van Asten et al. 2010; Schotte et al. 2004).

cCPB2 is a $27.6 \mathrm{kDa}$ protein that has been found poorly cytotoxic in the intestinal cell line I407 (Gibert et al. 1997). No cytotoxic effect related to cCPB2 with $C$. perfringens isolates from porcine or human origin was observed in the porcine intestinal cell line IPI-21 or the human epithelial colorectal adenocarcinoma cells CaCo-2 (Allaart et al. 2014). Recently, cCPB2 was reported to induce apoptosis and inflammatory response in intestinal porcine epithelial (JPEC-J2) cells (Gao et al. 2020; Luo et al. 2020a). $C$. perfringens produces numerous protein toxins and $C$. perfringens strains are divided into seven toxinotypes $(A-G)$ based on the combination of 6 toxins (alpha, CPB, epsilon (ETX), iota, enterotoxin (CPE), and NetB) (Rood et al. 2018). Despite a low level of amino sequence identity, most of $C$. perfringens toxins share a conserved structure of poreforming toxins (PFT) (Popoff 2014). cCPB2 was crystallized, but the structure has not been determined yet (Gurjar et al. 2007).

Here, we report the pore-forming activity of cCPB2 in lipid bilayer membranes. Our results define this toxin as a cation-selective pore-forming component, which could be the primary cause of its action on target cells. Net negative charges control ion transport through channels formed by cCPB2. Their electrophysiological properties resemble conductance, selectivity, and size of the channels formed by C. perfringens enterotoxin (CPE) (Benz and Popoff 2018). We provide also a comparison of the pore-forming characteristics caused by the different toxins of $C$. perfringens and related bacteria in the discussion.

\section{Materials and methods}

\section{Production and purification of consensus CPB2}

ccpb2 was PCR amplified from $C$. perfringens CWC245 (Waters et al. 2003) with the primers P2120 5'-GGATCC
AAAGAAATCGACGCTTAT-3' and P2121 5'-GTCGAC CTATGCACAATACCCTTCACC-3' adding BamH1SalI and cloned into pET28a and pGEX4T1 yielding the recombinant plasmid pMRP1318 coding for GST-cCPB2. Escherichia coli BL21 harboring pMRP1318 was grown in $\mathrm{LB}$ medium $(10 \mathrm{~g} / \mathrm{L}$ tryptone, $5 \mathrm{~g} / \mathrm{L}$ yeast extract, $10 \mathrm{~g} / \mathrm{L}$ $\mathrm{NaCl}, \mathrm{pH} 7.4)$ containing ampicillin $(100 \mathrm{mg} / \mathrm{mL})$ at $37^{\circ} \mathrm{C}$ with shaking to an optical density at $600 \mathrm{~nm}$ of 0.7 . The culture was induced with $1 \mathrm{mM}$ isopropyl b-D thiogalactoside (IPTG) and incubated with shaking at $18{ }^{\circ} \mathrm{C}$ overnight. All media for cell growth were obtained from Gibco (ThermoFisher Scientific). After centrifugation, the pellet was suspended in phosphate-buffered saline (PBS) containing protease inhibitors (complete EDTA free protease inhibitors, Roche) and sonicated. The cell debris was separated from the soluble fraction by centrifugation $(18,000 \mathrm{rpm}, 15 \mathrm{~min})$. The soluble fraction was applied onto a Glutathione Sepharose 4B column (GE Healthcare) equilibrated with PBS. The column was extensively washed with PBS and eluted with reduced glutathione $15 \mathrm{mg} / \mathrm{mL}$ in $50 \mathrm{mM}$ TRIS- $\mathrm{HCl} \mathrm{pH} 8$. The fractions containing GST-cCPB2 were pooled, dialyzed against $50 \mathrm{mM}$ TRIS-HCl, $\mathrm{NaCl} 150 \mathrm{mM}, \mathrm{pH}$ 7.5. Protein content was assayed with Coomassie brilliant blue G-250 (Bio-Rad protein assay). Cleavage by thrombin was performed with the Novagen thrombin kit $(69,022-3)$ according to the manufacturer's recommendations.

\section{Mass spectrometry}

Because of some inhomogeneity in the single-channel conductance histograms obtained for GST-cCPB2 and cCPB2 (see below), we subjected the GST-cCPB2 protein to mass spectrometry. The Coomassie-stained 1D-SDS gel band with GST-cCPB2 was worked up to generate tryptic peptides according to published protocols (Sinz et al. 2002; Konus et al. 2013; Röwer et al. 2018). Mass spectrometric analysis of peptide mixtures was performed in duplicate on a Synapt G2S mass spectrometer (Waters, Manchester, UK) using MassLynx version 4.1, coupled to a nanoACQUITY UPLC system (Waters MS-Technologies, Manchester, UK) via a NanoLockSpray ion source using a PicoTip Emitter (New Objective, Woburn, MA, USA) as described elsewhere (Sinz et al. 2002; Kumar et al. 2018). $\mathrm{MS}^{\mathrm{E}}$ data were processed using ProteinLynx Global SERVER version 2.3 (Waters MSTechnologies). Protein identifications and partial amino acid sequence assignments were obtained by searching against all entries of a UniProt/Swiss-Prot (UniProt release 2021_01) database to which the sequence information of GST-cCPB2 was manually added (Röwer et al. 2009; Postu et al. 2019). Search parameters were set to: two missed cleavage sites, oxidation of methionine residues as variable modification, and carbamidomethylation of cysteines as fixed modification. Peptides were identified by at least three fragment ions. 
Singly charged peptide ions were rejected, whereas peptides with two, three, and four positive charges were accepted. Furthermore, peptides were removed from the hit list that had (1) a peptide score below 5.5, (2) a mass error above $13 \mathrm{ppm}$, and (3) less than six amino acid residues in length. Amino acid sequence coverage was graphically displayed on the GST-beta2-toxin fusion protein sequence.

\section{Lipid bilayer experiments}

The methods used for the lipid bilayer measurements have been described previously in detail (Benz et al. 1978) from a $1 \%$ solution of diphytanoyl phosphatidylcholine, (DiPhPC; Avanti Polar Lipids, Alabaster, AL) in n-decane. The instrumentation consisted of a Teflon chamber with two aqueous compartments connected by a small circular hole with a surface area of about $0.4 \mathrm{~mm}^{2}$. The aqueous salt solutions (analytical grade; Merck, Darmstadt, Germany) were used unbuffered and had a pH around 6, because of the dissolved $\mathrm{CO}_{2}$ and the carbonic acid-bicarbonate equilibrium. Other $\mathrm{pH}$-values are indicated. Recombinant GST-cCPB2 and cCPB2 cleaved with thrombin was added from concentrated stock solutions to the aqueous phase bathing membranes in the black state. The temperature was kept at $20{ }^{\circ} \mathrm{C}$ throughout. The conductance experiments were performed using a pair of $\mathrm{Ag} / \mathrm{AgCl}$ electrodes with salt bridges switched in series with a voltage source and a highly sensitive current amplifier (Keithley 427, Keithley Instruments, Cleveland, Ohio). The amplified signal was monitored with a storage oscilloscope and the reconstitution of cCPB2 channels in the black lipid membrane was recorded with a strip chart recorder. Zero-current membrane potential measurements were obtained by establishing fivefold salt gradients across membranes containing about $100 \mathrm{cCPB} 2$ channels as described elsewhere (Benz et al. 1985).

\section{Influence of net negatively charged groups of ion conductance of CCPB2 channels}

The single-channel conductance of the cCPB2 channels was not a linear function of the bulk aqueous conductance (see "Results" section). One possibility to explain this effect represents a binding site inside the CCPB2 channel for cations or anions (Nelson and McQuarrie 1975; Benz and Hancock 1987; Trias and Benz 1993). Alternatively, it is also possible that charges at the pore mouth influence ion transport through cCPB2 channels. In such a case, the conductance depends on the square root of the bulk aqueous $\mathrm{KCl}$ concentration as it is shown in Table 1 (Trias and Benz 1993). The effect of point charges on channel conductance can be treated by a previously suggested formalism (Trias and Benz 1993). It assumes that the point charge is localized at the channel opening, where the negative charge $q$, causes a potential $\Phi$ on the mouth of a channel with a radius $r$, given by (Trias and Benz 1993):

$\Phi=\frac{2 q \cdot e^{-\frac{r}{l_{D}}}}{4 \pi \cdot \varepsilon_{0} \cdot \varepsilon \cdot r}$,

$\varepsilon_{0}\left(=8.85 \times 10^{-12} \mathrm{~F} / \mathrm{m}\right)$ and $\varepsilon(=80)$ are the absolute dielectric constant of vacuum and the relative constant of water, respectively, and $l_{D}$ is the so called Debye length, which controls the decay of the potential (and of the accumulated positively charged ions) in the aqueous phase (and also inside the channel:

$l_{D}^{2}=\frac{\varepsilon \cdot \varepsilon_{0} \cdot \boldsymbol{R} \cdot \boldsymbol{T}}{2 \cdot \boldsymbol{F}^{2} \cdot \boldsymbol{c}}$,

$c$ is the bulk aqueous salt concentration, and $R$ is the gas constant, $T$ the absolute temperature (in ${ }^{\circ} \mathrm{K}$ ), and $F$ the Faraday constant $\left(R T / F=25.2 \mathrm{mV}\right.$ at $\left.20^{\circ} \mathrm{C}\right)$. The concentration of the monovalent cations near the point charge increases because of the negative potential. Their concentration, $c_{0}^{+}$at the channel mouth is given by:

$c_{0}^{+}=c_{0} \cdot e^{-\frac{\Phi \cdot F}{R \cdot T}}$

The cation concentration, $c_{0}^{+}$, at the mouth of the pore can now be used for the calculation of the effective conductanceconcentration curve:

$\boldsymbol{G}(\boldsymbol{c})=\boldsymbol{G}_{0} \cdot \boldsymbol{c}_{0}^{+}$.

$G_{0}$ is the concentration independent conductance of the channel.

\section{Cell culture}

Vero, MDCK, HUVEC cells were grown in Dulbecco's modified Eagle medium (DMEM) + Glutamax ${ }^{\mathrm{TM}}$ (Gibco, Thermo Fisher Scientific) supplemented with $10 \%$ fetal calf serum (Gibco) and containing 100 units $/ \mathrm{mL}$ penicillin $\mathrm{G}$ sodium and $100 \mu \mathrm{g} / \mathrm{mL}$ streptomycin sulfate (Penicillin Streptomycin, Gibco) at $37{ }^{\circ} \mathrm{C}$ in a $5 \% \mathrm{CO}_{2}$ incubator. For cytotoxicity and propidium iodide (PI) (Roche) assays, cells were grown to confluency in 96-well plates. The monolayers were washed once in DMEM and incubated in PBS containing $5 \mathrm{mM}$ glucose, $0.1 \%$ BSA (Gibco) and serial dilutions of CPE in DMEM (100 $\mu$ l final volume in each well).

\section{Propidium iodide $(\mathrm{PI})$ influx}

For assay of (propidium iodide) PI entry, HUVEC cells were grown on 96-well plates until confluency. PI (Roche) $(5 \mu \mathrm{g} /$ $\mathrm{mL}$ ) was added in the culture medium together with toxins. The plates were read with a spectrofluorimeter (Fluoroskan II) (excitation $540 \mathrm{~nm}$ and emission $620 \mathrm{~nm}$ ) at 1, 2, 4, and 
$22 \mathrm{~h}$. The results were expressed as the percentage of fluorescence obtained by treatment with Triton X-100 (0.2\%) for $30 \mathrm{~min}$ at $37^{\circ} \mathrm{C}$.

\section{Results}

\section{Purification of GST-cCPB2 and CCPB2}

Purified recombinant GST-cCPB2 and cCPB2 as obtained by thrombin cleavage of GST-cCPB2 were essentially free of contaminant proteins as shown in Fig. 1 by a $10 \%$ SDS-PAGE. To verify that the $55 \mathrm{kDa}$ band in the SDS gel (Fig. 1A; lane 1) is indeed GST-cCPB2 and does not contain contaminant proteins, a $55 \mathrm{kDa}$ band from a similar SDS-PAGE experiment was excised and subjected to ingel trypsin treatment followed by peptide mass fingerprinting. Partial amino acid sequences of the GST-cCPB2 were matched to 209 peptide ion signals and resulted in a $96.7 \%$ amino acid sequence coverage (Fig. 1B), clearly identifying the protein. In addition, elongation factor Tu $(45-50 \mathrm{kDa})$ from $E$. coli was found to be present as minor contamination in the band (data not shown). The mass spectrometry results verified that we were indeed working with GST-cCPB2 and upon thrombin cleavage with cCPB2, respectively, as the only pore-forming compounds in the protein extracts.

\section{Pore-forming activity of GST-CCPB2 and CCPB2 toxin in lipid bilayers}

In a first set of experimental conditions, we studied the pore-forming ability of the recombinant GST-cCPB2 fusion product in lipid bilayer membranes made of $\mathrm{DiPhPC} / \mathrm{n}$ decane. Surprisingly, the addition of this construct in a concentration of about $3 \mu \mathrm{g} / \mathrm{mL}$ to black lipid bilayer membranes resulted in a strong increase of the membrane conductance within about $25 \mathrm{~min}$ (see Fig. 2). This result suggested that GST-cCPB2- represents a channel-forming component that could boost the conductance of artificial membranes. When we removed the GST-tag by treatment of GST-cCPB2- with thrombin and added cCPB2 in the same concentration to black lipid bilayer membranes, we observed a similar conductance increase. cCPB2 and GST-cCPB2- in a concentration of about $3 \mu \mathrm{g} / \mathrm{mL}$ had approximately the same effect on lipid membranes, i.e. the addition of both proteins resulted in a strong conductance increase from ground level conductance (about $10^{-7} \mathrm{~S} / \mathrm{cm}^{2}$ ) to $10^{-4} \mathrm{~S} / \mathrm{cm}^{2}$ within about half an hour as shown in Fig. 2. The addition of GST alone at the same concentration as the toxins did not result in any appreciable increase of membrane conductance as Fig. 2 clearly demonstrates.

\section{Single conductance of CCPB2 channels}

The addition of cCPB2 in a much smaller concentration than added above in the multi-channel experiments allowed the resolution of conductance steps as demonstrated in Fig. 3. Shortly after the addition of $30 \mathrm{ng} / \mathrm{mL}$ cCPB2 to one side of a black DiPhPC/n-decane membrane the conductance increased in discrete steps that indicated the formation of ion-permeable channels in the membrane. Most of the conductance steps were directed upward and terminating events were only rarely observed. This observation suggested long lifetimes of the channels
A

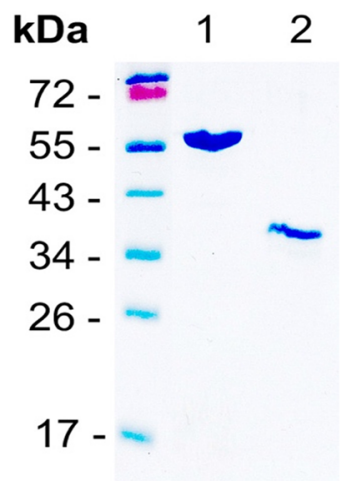

B

1 MSPILGYWKI GGLVQPTRLL LEYLEEKYEE HLYERDEGDK

41 WRNKKFELGL EFPNLPYYID GDVKLTQSMA IIRYIADKHN

81 MLGGCPKERA EISMLEGAVL DIRYGVSRIA YSKDFETLKV

121 DFLSKLPEML KMFEDRLCHK TYLNGDHVTH PDFMLYDALD

161 VVLYMDPMCL DAFPKLVCFK KRIEAIPQID KYLKSSKYIA

201 WPLQGWQATF GGGDHPPKSD LVPRGSKEID AYRKVMENYL

241 NALKNYDINT VVNISEDERV NNVEQYREML EDFKYDPNQQ

281 LKSFEILNSQ KSDNREIFNV KTEFLNGAIY DMEFTVSSKD

321 GKLIVSDMER TKVENEGKYI LTPSFRTQVC TWDDELAQAI

361 GGVYPQTYSD RFTYYADNIL LNFRQYATSG SRDLKVEYSV

401 VDHWMWKDDV KASQMVYGQN PDSARQIRLY IEKGQSFYKY

441 RIRIKNFTPA SIRVFGEGYC A

Fig. 1 A 10\% SDS-PAGE of purified consensus GST-CPB2, and consensus CPB2. Lane 1 shows $2 \mu \mathrm{g}$ of recombinant consensus GSTCPB2 dissolved in $10 \mu \mathrm{L}$ sample buffer according to Laemmli (1970); lane $2 \mu \mathrm{g}$ thrombin cleaved GST-CPB2. The left lane of the SDSPAGE shows the location of the molecular mass markers: 17, 26, 34, 43,55 , and $72 \mathrm{kDa}$. The gel was stained with Coomassie brilliant blue. B Graphical presentation of the amino acid sequence coverage after tryptic in-gel digestion of GST-cCPB2 excised from protein band in A, lane 1. Amino acid residues (single letter code) shown in black indicate the partial sequence of GST and those in blue that of CCPB2, which were represented by matching peptide ion signals. Amino acid residues shown in red point to partial sequences for which no matching peptide ion signals were observed by nanoLC-ESI-MS ${ }^{\mathrm{E}}$ analysis. Amino acid position numberings are given at the left 
formed by cCPB2, similar to channels formed by other toxins and binding proteins of A-B toxins of C. perfringens (Schmid et al. 1994; Petit et al. 2001; Knapp and Benz 2016; Benz and Popoff 2018). Channel formation was frequent, which allowed meaningful statistics of channels formed by cCPB2 in lipid bilayer membranes. For comparison, we also included into Fig. 3 also a current recording, which we obtained in single-channel experiments with uncleaved GST-cCPB2 under identical conditions to the trace in Fig. $3 \mathrm{~A}(1 \mathrm{M} \mathrm{KCl}, \mathrm{pH} 6)$. See the current trace in Fig. 3B.

Figure 4A shows a histogram of all conductance fluctuations observed with cCPB2 that was obtained by thrombin cleavage of GST-cCPB2. The distribution of cCPB2 channels showed two maxima. A minor fraction of about $25 \%$ of all fluctuations centered on $300 \mathrm{pS}$ and the major one with more than $50 \%$ of the channels around $700-800 \mathrm{pS}$ in $1 \mathrm{M} \mathrm{KCl}, \mathrm{pH} 6$. The mean value of all fluctuations was $642 \pm 63 \mathrm{pS}$. We performed also single-channel conductance measurements with GST-cCPB2 because this construct showed also membrane activity in multi-channel experiments. The current recordings with this construct showed similar fluctuations to cCPB2 as shown in Fig. 3B. However, statistics of the single-channels formed with this compound suggested that the conductance of the channels shown in Fig. 4B was on average slightly smaller than that for cCPB2. This could mean that the GST-tag attached to $\mathrm{CCPB} 2$ had some minor influence on the channel conductance possible caused by sterical hindrance of ion flux although it did not influence its membrane activity.

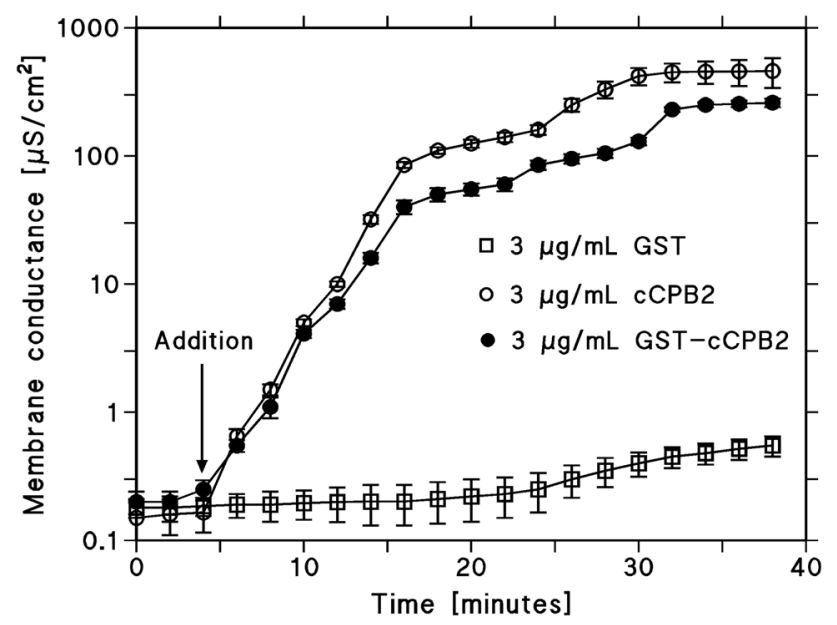

Fig. 2 Specific membrane conductance as a function of time after the addition of GST, GST-cCPB2, and cCPB2 to membranes formed of $\mathrm{DiPhPC} / \mathrm{n}$-decane. The arrow indicates the addition of the three compounds in a concentration of $3 \mu \mathrm{g} / \mathrm{mL}$ to the aqueous phase bathing individual black bilayers. The data points show the mean \pm SD of three experiments. The aqueous phase contained $1 \mathrm{M} \mathrm{KCl,} \mathrm{pH}$ 6. The applied voltage was $20 \mathrm{mV} ; T=20^{\circ} \mathrm{C}$

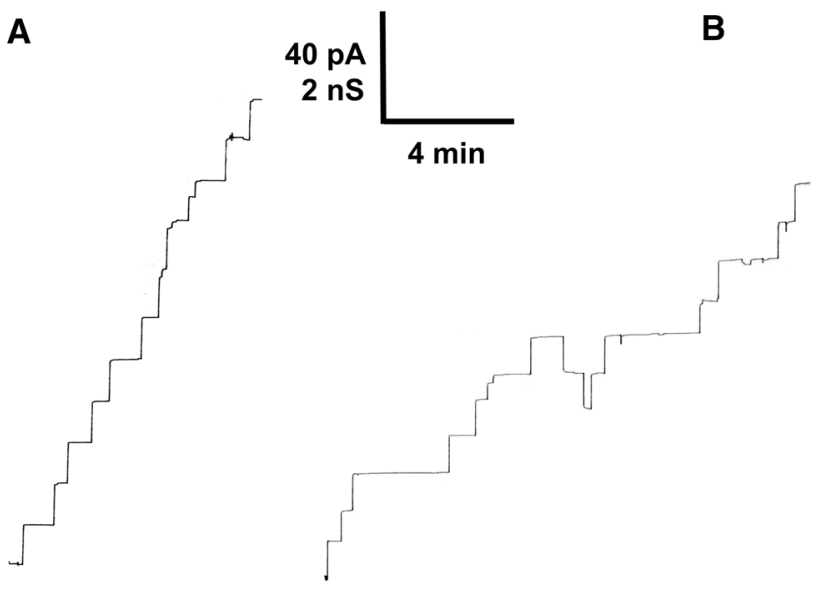

Fig. 3 Single-channel recording of a $\mathrm{DiPhPC} / n$-decane membrane in the presence of cCPB2 of $C$. perfringens cleaved with thrombin (A) and GST-cCPB2 (B). The aqueous phase contained unbuffered $1 \mathrm{M}$ $\mathrm{KCl}, \mathrm{pH} 6.0$, and about $30 \mathrm{ng} / \mathrm{mL} \mathrm{cCPB} 2$ (A) and about $40 \mathrm{ng} / \mathrm{mL}$ GST-cCPB2 (B). The applied membrane potential was $20 \mathrm{mV}$ and the temperature was $20{ }^{\circ} \mathrm{C}$. The recording was performed with the strip chart recorder at a time resolution of $10 \mathrm{~Hz}$

\section{Single-channel analysis}

Because of the slight difference between the single-channel conductance observed with GST-cCPB2 and cCPB2 cleaved with thrombin we performed all further experiment with cCPB2. In particular, we measured the single-channel conductance of $\mathrm{cCPB} 2$ channels for a variety of $\mathrm{KCl}-\mathrm{con}$ centrations and for $1 \mathrm{M} \mathrm{KCH}_{3} \mathrm{COO}^{-}$and $1 \mathrm{M} \mathrm{LiCl}$. The experiments were performed similarly to those of Figs. 3 and 4 . The results are listed in Table 1 . For all conditions,

Table 1 Average single-channel conductance of cCPB2 of C. perfringens in different electrolyte solutions

\begin{tabular}{llcc}
\hline Electrolyte & $\begin{array}{l}\text { Concentration } \\
(\mathrm{M})\end{array}$ & $\mathrm{G}(\mathrm{pS})$ & $N$ \\
\hline $\mathrm{KCl}$ & 0.01 & $53 \pm 9$ & 110 \\
& 0.03 & $94 \pm 11$ & 134 \\
& 0.1 & $219 \pm 19$ & 131 \\
& 0.15 & $243 \pm 15$ & 121 \\
& 0.3 & $350 \pm 32$ & 127 \\
& 1.0 & $642 \pm 63$ & 320 \\
& 3.0 & $1060 \pm 95$ & 149 \\
$\mathrm{LiCl}$ & 1.0 & $188 \pm 24$ & 105 \\
$\mathrm{KCH}_{3} \mathrm{COO}(\mathrm{pH} 7)$ & 1.0 & $577 \pm 63$ & 196 \\
\hline
\end{tabular}

cCPB2 was obtained by thrombin cleavage of GST-cCPB2. The membranes were formed from diphytanoyl phosphatidylcholine/ in $n$-decane. The single-channel conductance was measured at $20 \mathrm{mV}$ applied voltage and $T=20{ }^{\circ} \mathrm{C}$. $\mathrm{N}$ is the number of events used for the calculation of the average single-channel conductance $G( \pm S D)$. Measurements in K-acetate were performed at $\mathrm{pH} 7$, because of incomplete dissociation of potassium acetate at $\mathrm{pH} 6$ 


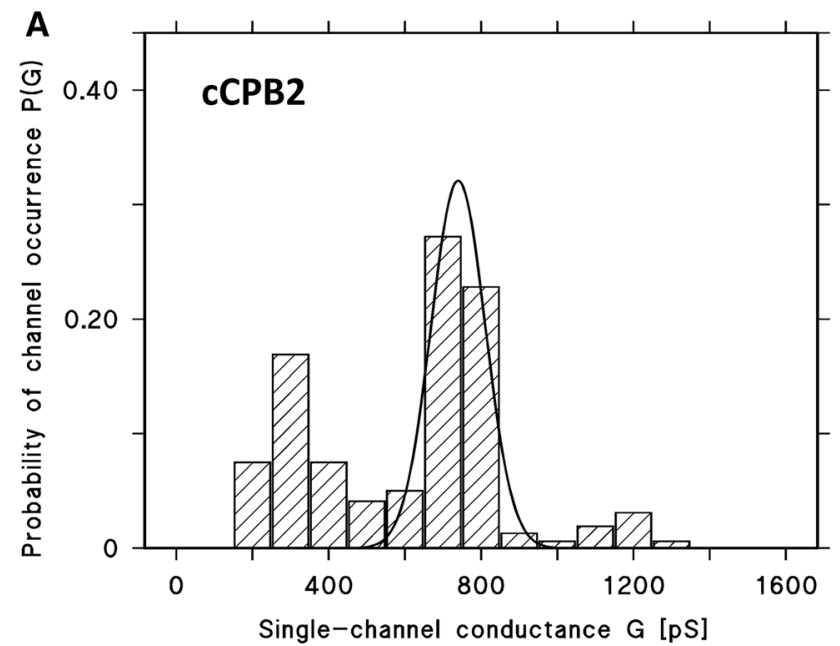

Fig. 4 Histogram of the probability $\mathrm{P}(\mathrm{G})$ for the occurrence of a given conductivity unit in $\mathrm{DiPhPC} / n$-decane membranes in the presence of cleaved cCPB2 and GST-cCPB2 of $C$. perfringens. The probability of channel occurrence was calculated by dividing the number of fluctuations with a given conductance unit by the total number of conductance fluctuations in the presence of cCPB2 and GST-cCPB2, respectively. A The mean value of the single-channel conductance of all conductance fluctuations was $643 \mathrm{pS}$ for 320 single-channel events collected from different individual membranes. Aqueous phase contained $1 \mathrm{M} \mathrm{KCl}, \mathrm{pH} 6$, and about $30 \mathrm{ng} / \mathrm{mL}$ cCPB2 cleaved with thrombin. The applied voltage was $20 \mathrm{mV}$ and the temperature was $20{ }^{\circ} \mathrm{C}$. The solid line shows a fit of the histogram with a Gaussian

the single-channel conductance showed a major maximum for about $50-70 \%$ of all conductance fluctuations. A minor peak of about $30-40 \%$ of all steps had a conductance that was about half of the major peak. The single-channel measurements under the different conditions were performed to see whether the single-channel conductance was a linear function of the bulk aqueous $\mathrm{KCl}$ concentration. Similarly, we exchanged in the salt solutions, mobile potassium ions and chloride by the less mobile $\mathrm{Li}^{+}$and acetate ions to get some information about size and selectivity of the channels formed by cCPB2. The results of these measurements are summarized in Table 1. They clearly demonstrate that the single-channel conductance did not follow a linear function of the bulk aqueous concentration, which indicated that the movement of ions through the cCPB2 channels is controlled by net charges in or near the channels, i.e. they are highly selective. This can also be judged from the measurements in $1 \mathrm{M} \mathrm{LiCl}$ and $1 \mathrm{M} \mathrm{KCH}_{3} \mathrm{COO}^{-}$. The exchange of chloride by the less mobile acetate had an only minor effect on the single-channel conductance whereas the replacement of $\mathrm{K}^{+}$ by the less mobile $\mathrm{Li}^{+}$changed substantially channel conductance indicating its cation selectivity. The measurements with potassium acetate were performed at $\mathrm{pH} 7$ because of incomplete dissociation of $\mathrm{KCH}_{3} \mathrm{COO}^{-}$at $\mathrm{pH}$ 6. Singlechannel experiments at different $\mathrm{pH}$-values between $\mathrm{pH} 5$

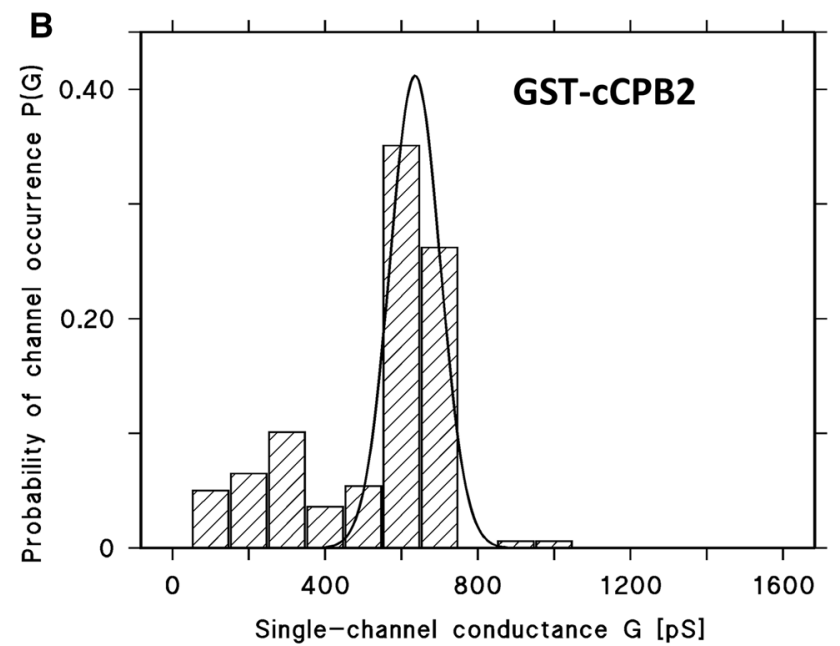

distribution. The maximum of the distribution is at a probability of $0.321 \pm 0.082$ and the conductance is $740 \pm 71 \mathrm{pS}$ for all single events taken from nine individual membranes. B The mean value of the single-channel conductance of all conductance fluctuations with GST-cCPB2 was $530 \mathrm{pS}$ for 168 single-channel events collected from different individual membranes. The aqueous phase contained $1 \mathrm{M}$ $\mathrm{KCl}$, pH6, and about $40 \mathrm{ng} / \mathrm{mL}$ GST-cCPB2. The applied voltage was $20 \mathrm{mV}$ and the temperature was $20^{\circ} \mathrm{C}$. The solid line shows a fit of the histogram with a Gaussian distribution. The maximum of the distribution is at a probability of $0.412 \pm 0.061$ and the conductance is $636 \pm 66 \mathrm{pS}$ for all single events taken from five individual membranes

and $\mathrm{pH} 8$ showed that channel-forming activity and channel conductance did not change in this $\mathrm{pH}$-range.

\section{Selectivity of the CCPB2 channel}

To confirm the possible cation selectivity of the cCPB2 channel, we performed zero-current membrane potential measurement in the presence of fivefold salt gradients of $\mathrm{KCl}, \mathrm{LiCl}$, and $\mathrm{KCH}_{3} \mathrm{COO}^{-}$. The salt gradients were established when about 100-1000 cCPB2 channels were reconstituted into the lipid bilayers. Afterwards the instrumentation was switched to the measurement of zero-current membrane potentials. The potential turned in all experiments to positive values at the more dilute side $(0.1 \mathrm{M})$ of the membranes containing cCPB2 channels. These results indicated again preferential movement of cations for all three salts. The analysis of the zero-current membrane potentials using the Goldman-Hodgkin-Katz equation (Benz et al. 1985) demonstrated indeed that cCPB2 formed highly cation-selective channels with permeability ratios for cations and anions that were around ten and higher for all three salts studied here (Table 2). Similar permeability ratios were also found for CPE (Benz and Popoff 2018) and Beta toxin (CPB) of $C$. perfringens (Shatursky et al. 2000), whereas ETX-channels were preferentially anion selective (Petit et al. 2001). 


\section{Cell cytotoxicity}

GST-cCPB2 and $C$. perfringens enterotoxin (CPB) were tested for cytotoxicity in human umbilical endothelial cells (HUVEC) by monitoring the entry of propidium iodide (PI) as already used for other $C$. perfringens pore-forming toxins such as $C$. perfringens enterotoxin (CPE) or $C$. perfringens epsilon toxin (Petit et al. 2003; Benz and Popoff 2018). CPB has been found to be specifically cytotoxic for endothelial cells (Gurtner et al. 2010; Popescu et al. 2011). Indeed, as shown in Fig. 5B, CBP efficiently promoted entry of PI into HUVEC cells. In contrast, cCPB2 showed a weak activity in HUVEC (see Fig. 5A). Only a prolonged incubation with cCPB2 to $22 \mathrm{~h}$ induced significant PI entry into cells, whereas CPB caused higher effects at earlier incubation times in the same range of toxin concentrations. No activity was observed with CCPB2 or CPB in intestinal or kidney

Table 2 Zero-current membrane potentials, $V_{\mathrm{m}}$, of DiphPC/n-decane membranes in the presence of $C$. perfringens consensus Beta2 toxin (cCPB2) measured for fivefold gradients of different salts ${ }^{\mathrm{a}}$

\begin{tabular}{lcc}
\hline Electrolyte & Permeability ratios & $V_{\mathrm{m}}(\mathrm{mV})$ \\
& $P_{\text {cation }} / P_{\text {anion }}$ & \\
\hline $\mathrm{KCl}$ & 11.8 & $33.0 \pm 1.8$ \\
$\mathrm{LiCl}$ & 9.8 & $30.9 \pm 1.5$ \\
$\mathrm{KCH}_{3} \mathrm{COO}^{-}(\mathrm{pH} 7)$ & 15.0 & $34.5 \pm 2.1$ \\
\hline
\end{tabular}

${ }^{\mathrm{a}} V_{\mathrm{m}}$ is defined as the difference between the potential at the dilute side minus the potential at the concentrated side. The aqueous salt solutions were used unbuffered and had a $\mathrm{pH}$ of 6 , if not indicated otherwise; $T=20{ }^{\circ} \mathrm{C}$. The permeability ratios $P_{\text {cation }} / P_{\text {anion }}$ were calculated from the zero-current potentials using the Goldman-Hodgkin-Katz equation (Benz et al. 1985). The zero-current potentials are given as the mean $( \pm \mathrm{SD})$ of at least three individual experiments. Measurements in K-acetate were performed at $\mathrm{pH} \mathrm{7,} \mathrm{because} \mathrm{of}$ incomplete dissociation of potassium acetate at $\mathrm{pH} 6$

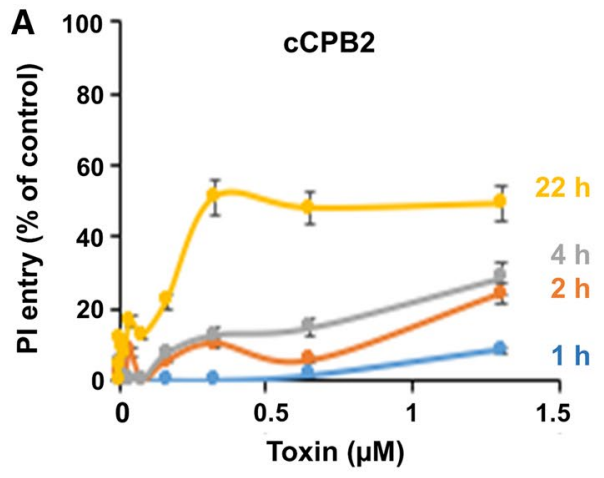

Fig. 5 Cytotoxicity of GST-cCPB2 (A) and CPB (B) in HUVEC cells monitored by PI entry. HUVEC cells in DMEM medium containing $5 \mu \mathrm{g} / \mathrm{mL}$ were incubated with GST-cCPB2 (A) or CPB (B) for 1-22 h at $37^{\circ} \mathrm{C}$. PI entry was monitored by spectrofluorometry. The data are epithelial cells (CaCo-2, Vero, MDCK cells) as monitored by PI entry or with viability test (WST-1).

\section{Discussion}

\section{Consensus CPB2 is a channel-forming toxin}

In contrast to CPB that is specifically cytotoxic for endothelial cells (Gurtner et al. 2010; Popescu et al. 2011), recombinant cCPB2 showed a weaker cytotoxicity in human endothelial cells (HUVEC), and no one in intestinal and kidney epithelial cells as tested in Vero, MDCK, and CaCo-2 cells. This does not preclude that $\mathrm{CCPB} 2$ and $\mathrm{aCPB} 2$ recognize specific cell type of cell subsets. Indeed, ETX is active in only a small number of kidney cell lines (Popoff 2011). Initially, cCPB2 was found to induce rounding of intestinal epithelial cells 1407 (Gibert et al. 1997). More recently, cCPB2 was reported to be cytotoxic for intestinal porcine epithelial (JPEC-J2) cells and to disrupt the intercellular junctions (Gao et al. 2020; Luo et al. 2020a). The cCPB2induced inflammatory response and apoptosis seems to be regulated by micro RNAs (Gao et al. 2021a, b; Luo et al. 2020b). Thereby, cCPB2 possibly promotes cytotoxic activity only in specific cell lines.

Nevertheless, it is clear from the data presented here that $\mathrm{CCPB} 2$ is a channel-forming toxin. This comes in particular from the high pore-forming activity of both GST-cCPB2 and CCPB2 obtained by cleavage with thrombin. Both proteins formed well-defined channels with a long lifetime, which is quite typical for channel-forming toxins. We observed channels with two different conductance values: a minor fraction had a conductance of about $300 \mathrm{pS}$ in $1 \mathrm{M} \mathrm{KCl}$, whereas more than $50 \%$ of all channels had a conductance around $700 \mathrm{pS}$. Careful analysis of the current recordings suggested that the channel with

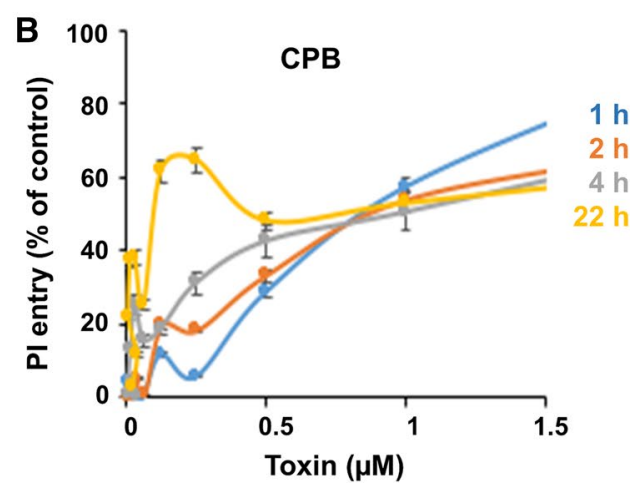

expressed as percentages of fluorescence compared to the control consisting of cells treated with $0.2 \%$ Triton X-100. Data were collected from three experiments and means and standard deviation were calculated 
the higher conductance was not caused by simultaneous insertion of two small channels or by impurities within cCPB2. It seems, moreover, that the formation of two types of channels is an intrinsic property of the pure cCPB2. We could speculate that the number of cCPB2 monomers in a channel-forming unit is responsible for the two types of channels. Many of the pore-forming toxins (Kitadokoro et al. 2011; Iacovache et al. 2016; Savva et al. 2019); and the binding components of the A-B toxins form channels with seven subunits (Barth et al. 2004; Schleberger et al. 2006; Jiang et al. 2015). Indeed, variability in channel conductance, likely due to different oligomer size (hexamer/heptamer), has been observed with CPB and Staphylococcus aureus alpha-hemolysin (Czajkowsky et al. 1998; Shatursky et al. 2000; Song et al. 1996). This could also be the case for cCPB2 because of its low homology to CPB. A change in the stoichiometry of the channel-forming complex to six monomers could well account for channels that have a smaller single-channel conductance.

\section{Beta-strands form presumably the consensus CPB2 channel}

Several versions of CPB2 are known. We performed here experiments with the plasmid-encoded cCPB2 (accession number AAC27654; (Gibert et al. 1997)). The other version of CPB2, also known as atypical CPB2 (WP_096517132; (Jost et al. 2005)) has identity to cCPB2 of $62.3 \%$ and similarity of $24.9 \%$. Differences are $12.8 \%$. Figure 6 shows an alignment of cCPB2 with aCPB2 using ClustalW multiple alignment (https://npsa.lyon.inserm.fr/cgi-bin/align_clust alw.pl). The alignment demonstrates the high homology between both toxins. There exists only little doubt that also atypical Beta2 is a channel-forming component because of its high homology to cCPB2.

To get some insight in the putative channel structure we studied the secondary structure of cCPB2 using public domain programs (for example https://npsa-prabi.ibcp.fr/ cgi-bin/secpred_consensus.pl). These programs suggested an only very small fraction of $\alpha$-helical stretches of amino acids for both Beta2 toxins (cCPB2 and aCPB2) that are not sufficient to cross a membrane. This means presumably that they are not channel-forming proteins that have an $\alpha$-helical backbone. The content of stretches with $\beta$-depleted sheets was much higher. Nevertheless, the search for transmembrane $\beta$-strands in both primary sequences with PREDTMBB (http://bioinformatics.biol.uoa.gr/PRED-TMBB/ input.jsp) did not classify both proteins as transmembrane proteins in terms of bacterial outer membrane proteins. This means presumably that only a small part of cCPB2, for instance one or two $\beta$-hairpins are involved in the channel similar as for other toxins, including CPB (Shatursky et al. 2000) as it is shown in Fig. 7 for the analysis of the mature cCPB2 protein with PRED-TMBB. In this figure, red colored stretches of amino acids could form $\beta$-strands in membranes. Water-soluble parts of the sequence are given in green and in blue. Taken together, this suggests that cCPB2 could be a member of (pore-forming toxins) PFT containing $\beta$-strands.
Fig. 6 Amino acid sequence alignment of cCPB2 and aCPB2 of $C$. perfringens. The alignment was performed using the NCBI Reference protein sequences WP_096517132 and AAC27654, respectively, and Pole Bioinformatique Lyonnaise Network Protein Sequence Analysis (https://npsa.lyon. inserm.fr/cgi-bin/align_clust alw.pl). Amino acids identical in the two proteins are highlighted in red $(*)$, strongly similar amino acids (:) are given in green and weakly similar ones (.) in blue. The mature amino acid sequence starts for both proteins with amino acid 31
CCPB2

aCPB2

CCPB2

aCPB2

CCPB2

aCPB2

CCPB2

aCPB2

CCPB2

aCPB2

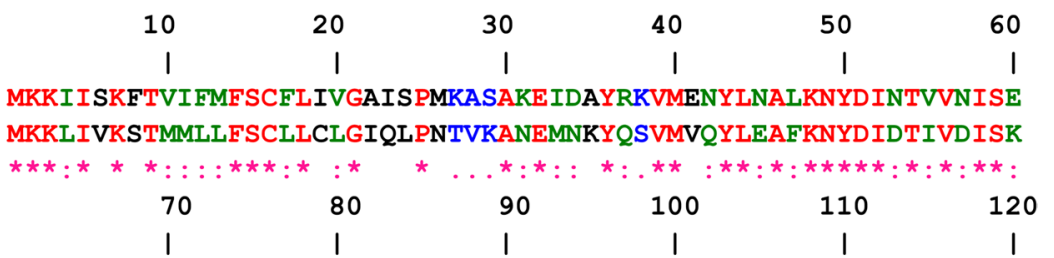

DERVNNVEQYREMLEDFKYDPNQQLKSFEILNSQKSDNKEIFNVKTEFLNGAIYDMEFTV DSRAVTREEYKNMLMEFRYDPNQKLKSYEITGSRKIDNGE IFSVRTEFLNGAIYNMEFTV

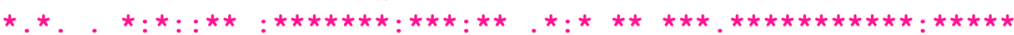
$\begin{array}{llllll}130 & 140 & 150 & 160 & 170 & 180\end{array}$ $\begin{array}{lllll}1 & 1 & 1 & 1 & 1\end{array}$ SSKDGKLIVSDMERTKVENEGKYILTPSFRTQVCTWDDELAQAIGGVYPQTYSDRFTYYA SYIDNKLMVSNMNRISIVNEGKCIPTPSFRTQVCTWDDELSQYIGDAVSFTRSSKFQYSS

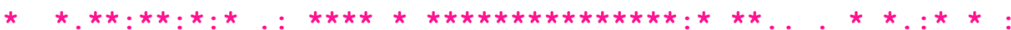

\begin{tabular}{cccccc}
190 & 200 & 210 & 220 & 230 & 240 \\
\hline & 1 & 1 & I & I & I
\end{tabular}

DNILLNFRQYATSGSRDLKVEYSVVDHWMWKDDVKASQMVYGQNPDSARQIRLYIEKGQS NTITLNFRQYATSGSRSLKVKYSVVDHWMWGDDIRASQWVYGENPDYARQIKLYLGSGET

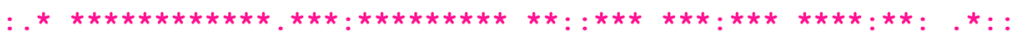

$250 \quad 260$

1

FYKYRIRIKNFTPASIRVFGEGYCA FKNYRIKVENYTPASIKVFGEGYCY

$\star: * * *::: *: * \star * \star *: * * * * * \star *$ 


\section{Negative charges control ion transport through the consensus CPB2 channels}

The analysis of the single-channel conductance and the selectivity of the CPB2 channels demonstrated that negative charges are involved in ion transport. A fit of the single-channel conductance as a function of the bulk aqueous concentration using Eqs. (1-4) allows some insight in the properties of the cCPB2 channel. Figure 8 shows the fit of the data using two parameters, the presumed radius $r$ of the channel and the charge q. The latter number has to be taken as tentative because the dielectric constant of the material (lipid, protein, water) near the charge is largely unknown (Trias and Benz 1993). The size of the cCPB2 channel should on the other hand be more precise because it is controlled by the decay of the electrical potential in the aqueous phase, which should be given by the Debye length, also in an aqueous channel (Trias and Benz 1993). According to the fit, the diameter of the consensus CPB2 channel should be around $1.4 \mathrm{~nm}$, which means that neutral or positively charged molecules with a molecular mass up to $600 \mathrm{Da}$ could permeate the channel formed by cCPB2. A diameter of $1.4 \mathrm{~nm}$ is very similar to that of the CPE channel and to the diameters of the other toxin channels listed in Table 3 with the exception of that formed by the $C$. septicum alphatoxin (Knapp et al. 2010). Heptamers form presumably all these channels by contributing seven $\beta$-hairpins to it.

\section{Toxins/proteins related to CCBP2}

We performed a BLAST search (https://blast.ncbi.nlm.nih. gov/Blast.cgi) for proteins that are related to cCPB2. We obtained four proteins that are in sequence and length related to $\mathrm{CCPB} 2$, which means presumably that they act also as toxins. The highest homology to $\mathrm{CCPB} 2$ has a hypothetical

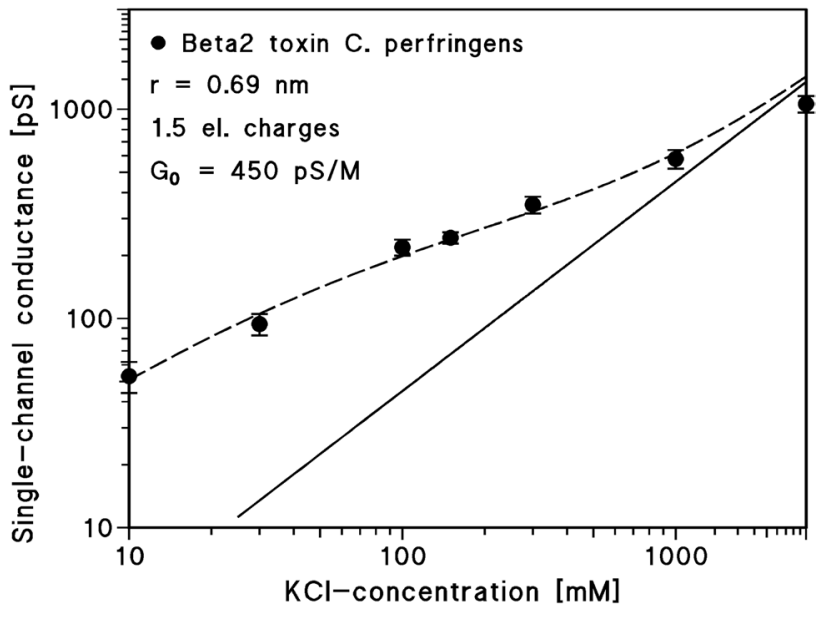

Fig. 8 Single-channel conductance of the cCPB2 channel of $C$. perfringens as a function of the $\mathrm{KCl}$ concentration in the aqueous phase. The broken line represents the fit of the single-channel conductance data (filled circles \pm SD, taken from Table 1) with Eqs. (1-4), using 1.5 negative point charges $\left(q=-2.4 \times 10^{-19}\right.$ As) and a channel diameter of about $1.4 \mathrm{~nm}$ as fit parameters. The straight line shows the single-channel conductance of consensus CPB2 that would be expected without point charges assuming a single-channel conductance of 450 pS/M. It corresponds to a linear graph between channel conductance and bulk aqueous. The number of single events used to calculate the average single-channel conductance (and SD) is given in Table 1, column 4

protein from Streptococcus equi (WP_059215460), where the mature protein is identical to the mature cCPB2. The next relative is a hypothetical protein FILTAT 026 (VDC 18093; 269 aa) from the Firmicute bacterium Filibacter sp. TB-66, which is with a similarity of only $20.77 \%$ already distantly related to cCPB2. An even smaller similarity to CCPB2 has a hypothetical protein (280 aa, WP_038589032.1) from the Firmicute Paenibacillus sp. FSL H7-0357, which has only
Fig. 7 Analysis of the secondary structure of the mature form of cCPB2 (without signal sequence) for $\beta$-strands using PRED-TMBB (http://bioin formatics.biol.uoa.gr/PREDTMBB/input.jsp). Amino acid stretches that could form transmembrane $\beta$-strands are colored in red. Stretches in blue or in green are exposed to different sides of the membrane to the aqueous phases. Some of the green stretches could form turns between two beta-strands
KEIDAYRKVMENYLNALKNYDINTVVNISEDERVNNVEQY

REMLEDFKYDPNQQLKSFEILNSQKSDNKEIFNVKTEFLN GAIYDMEFTVSSKDGKLIVSDMERTKVENEGKYILTPSFR TQVCTWDDELAQAIGGVYPQTYSDRFTYYADNILLNFRQY ATSGSRDLKVEYSVVDHWMWKDDVKASQMVYGQNPDSARQ 
Table 3 Comparison of the channel properties of cCPB2 with those of $C$. perfringens enterotoxin (CPE), aerolysin of Aeromonas sobria, alphatoxin of Staphylococcus aureus, epsilon toxin of C. perfringens (ETX) and Clostridium septicum alpha-toxin

\begin{tabular}{|c|c|c|c|}
\hline Toxin & $\begin{array}{l}\text { Single-channel conduct- } \\
\text { ance in } 1 \mathrm{M} \mathrm{KCl} \\
\mathrm{G}[\mathrm{pS}]\end{array}$ & $\begin{array}{l}\text { Zero-current membrane potential } \\
\text { for fivefold } \mathrm{KCl} \text { gradients } \\
V_{\mathrm{m}}[\mathrm{mV}]\end{array}$ & $\begin{array}{l}\text { Permeability } \\
\text { ratio } P_{\mathrm{K}} / P_{\mathrm{Cl}} \\
P_{\mathrm{K}} / P_{\mathrm{Cl}}\end{array}$ \\
\hline cCPB2 & 642 & +33 & 11.8 \\
\hline CPE & 623 & +33 & 11.4 \\
\hline Aerolysin & 650 & -24 & 0.21 \\
\hline S. aureus $\alpha$-toxin & 820 & -22 & 0.25 \\
\hline ETX & 550 & -19 & 0.30 \\
\hline C. septicum alpha-toxin & 1250 & -15 & 0.38 \\
\hline \multicolumn{4}{|c|}{$\begin{array}{l}V_{\mathrm{m}} \text { is the electrical potential on the dilute side minus the potential of the concentrated side for } \\
\text { a fivefold } \mathrm{KCl} \text {-gradient across the membranes. The membranes were formed from diphytanoyl } \\
\text { phosphatidylcholine } / n \text {-decane. The aqueous salt solutions were unbuffered and had a pH value of about } \\
\text { 6. The permeability ratio, } P_{\mathrm{K}} / P_{\mathrm{Cl}} \text {, was calculated using the Goldman-Hodgkin-Katz equation (Benz et al. } \\
\text { 1985). The results for epsilon toxin were taken from Petit et al. (2001) and those for aerolysin and } \alpha \text {-toxin } \\
\text { were taken from Chakraborty et al. (1990). The results for } C \text {. septicum alpha-toxin were taken from Knapp } \\
\text { et al. (2010) }\end{array}$} \\
\hline
\end{tabular}

a similarity of $18.3 \%$. For these proteins, cCPB2, aCPB2 and $\mathrm{CPB}$, we constructed a phylogenetic tree of the CPB2like proteins from Firmicutes using the program MEGA7 (Kumar et al. 2016). The results are shown in Fig. 9.

There exist presumably more proteins from the phylum Firmicutes that could be related to cCPB2. However, when the relation is too distant, these proteins are no longer recognized by the BLAST search. The interesting point is in any case that the bacteria producing proteins related to CPB2 belong all to the phylum Firmicutes.

\section{Conclusion}

Here, we show that cCPB2 is a PFT which forms cationselective channels of about $1.4 \mathrm{~nm}$ diameter in lipid bilayers. The lack of predicted long alpha-helical structures in cCPB2 amino acid sequence suggests that cCPB2 does not belong to the family of toxins, where the channels are lined up by $\alpha$-helices ( $\alpha$-PFTs). Figure 7 suggests that it is possible that the pore is lined up by $\beta$-strands ( $\beta$-PFTs) because some amino acid stretches in the primary sequence of cCPB 2 can

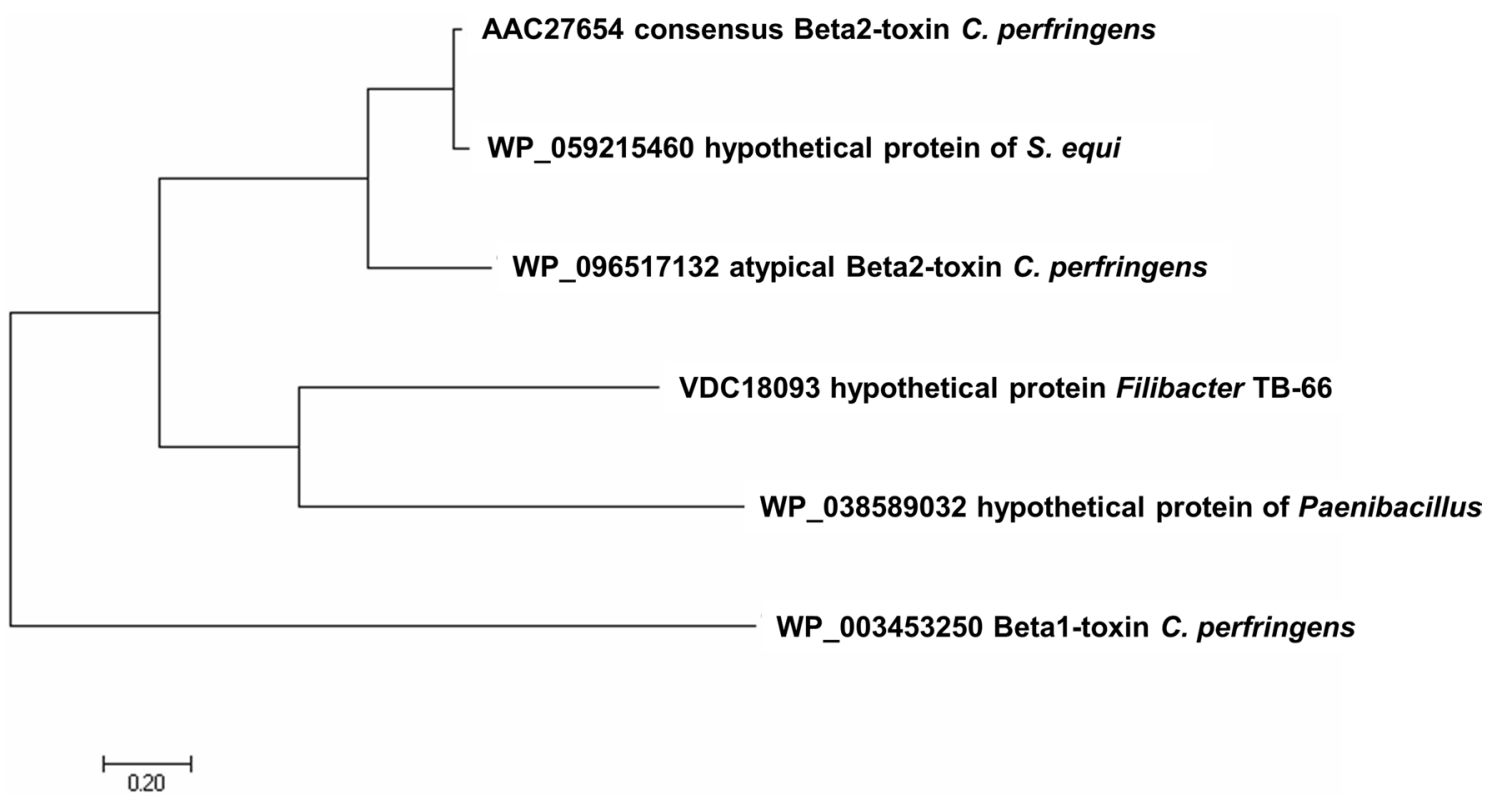

Fig. 9 Cladogram representing the phylogenetic relationships of Beta2 toxin like proteins from different Firmicutes. The tree was generated using protein sequences downloaded from the NCBI protein database with the indicated identifiers. The multiple sequence align- ment was calculated with Multiple Sequence Alignment (MUSCLE) (https://www.ebi.ac.uk/Tools/msa/muscle/). The tree was obtained using the program MEGA7 (Kumar et al. 2016) 
serve as amphipathic transmembrane $\beta$-hairpins. This is supported by the fact that $C$. perfringens produces numerous beta-strand PFTs, which despite low amino acid sequence homology share conserved structures. No alpha-helical PFT has been identified in C. perfringens (Popoff 2014). Pore formation likely accounts for the biological activities of cCPB2.

Acknowledgements The authors would like to thank Eva Waltenberger and Elke Maier for expert technical assistance. This work was financially supported by the Deutsche Forschungsgemeinschaft.

Author contributions RB and MRP conceived the presented idea; RB acquired the experimental data with inputs from $\mathrm{CP}, \mathrm{CH}, \mathrm{CK}$, and MRP; RB verified the analytical methods and analyzed the obtained data with inputs from $\mathrm{CP}, \mathrm{CH}, \mathrm{CK}$, and MOG; RB took the lead for writing together with MRP; all authors commented on previous versions of the manuscript. All authors read and approved the final manuscript.

Funding Open Access funding enabled and organized by Projekt DEAL. Deutsche Forschungsgemeinschaft Project BE865/16-2.

Availability of data and material All the data are available in the manuscript.

Code availability Not applicable.

\section{Declarations}

Conflict of interest The authors declare that they have no conflicts of interest or competing interests.

Open Access This article is licensed under a Creative Commons Attribution 4.0 International License, which permits use, sharing, adaptation, distribution and reproduction in any medium or format, as long as you give appropriate credit to the original author(s) and the source, provide a link to the Creative Commons licence, and indicate if changes were made. The images or other third party material in this article are included in the article's Creative Commons licence, unless indicated otherwise in a credit line to the material. If material is not included in the article's Creative Commons licence and your intended use is not permitted by statutory regulation or exceeds the permitted use, you will need to obtain permission directly from the copyright holder. To view a copy of this licence, visit http://creativecommons.org/licenses/by/4.0/.

\section{References}

Allaart JG, de Bruijn ND, van Asten AJ, Fabri TH, Gröne A (2012) NetB-producing and beta2-producing Clostridium perfringens associated with subclinical necrotic enteritis in laying hens in the Netherlands. Avian Pathol 41(6):541-546

Allaart JG, van Asten AJ, Vernooij JC, Gröne A (2014) Beta2 toxin is not involved in in vitro cell cytotoxicity caused by human and porcine cpb2-harbouring Clostridium perfringens. Vet Microbiol 171(1-2):132-138

Barth H, Aktories K, Popoff MR, Stiles BG (2004) Binary bacterial toxins: biochemistry, biology, and applications of common Clostridium and Bacillus proteins. Microbiol Mol Biol Rev 68(3):373-402
Benz R, Hancock RE (1987) Mechanism of ion transport through the anion-selective channel of the Pseudomonas aeruginosa outer membrane. J Gen Physiol 89(2):275-295

Benz R, Popoff MR (2018) Clostridium perfringens enterotoxin: the toxin forms highly cation-selective channels in lipid bilayers. Toxins (basel) 10(9):341

Benz R, Janko K, Boos W, Läuger P (1978) Formation of large, ionpermeable membrane channels by the matrix protein (porin) of Escherichia coli. Biochim Biophys Acta 511(3):305-319

Benz R, Schmid A, Hancock RE (1985) Ion selectivity of gram-negative bacterial porins. J Bacteriol 162(2):722-727

Bueschel DM, Jost BH, Billington SJ, Trinh HT, Songer JG (2003) Prevalence of cpb2, encoding beta2 toxin, in Clostridium perfringens field isolates: correlation of genotype with phenotype. Vet Microbiol 94(2):121-129

Carman RJ, Sayeed S, Li J, Genheimer CW, Hiltonsmith MF, Wilkins TD, McClane BA (2008) Clostridium perfringens toxin genotypes in the feces of healthy North Americans. Anaerobe 14(2):102-108

Chakraborty T, Schmid A, Notermans S, Benz R (1990) Aerolysin of Aeromonas sobria: evidence for formation of ion-permeable channels and comparison with alpha-toxin of Staphylococcus aureus. Infect Immun 58(7):2127-2132

Chan G, Farzan A, Soltes G, Nicholson VM, Pei Y, Friendship R, Prescott JF (2012) The epidemiology of Clostridium perfringens type A on Ontario swine farms, with special reference to cpb2positive isolates. BMC Vet Res 8:156

Czajkowsky DM, Sheng S, Shao Z (1998) Staphylococcal alphahemolysin can form hexamers in phospholipid bilayers. J Mol Biol 276:325-330

Farzan A, Kircanski J, DeLay J, Soltes G, Songer JG, Friendship R, Prescott JF (2013) An investigation into the association between cpb2-encoding Clostridium perfringens type A and diarrhea in neonatal piglets. Can J Vet Res 77(1):45-53

Ferrarezi MC, Cardoso TC, Dutra IS (2008) Genotyping of Clostridium perfringens isolated from calves with neonatal diarrhea. Anaerobe 14(6):328-331

Fisher DJ, Miyamoto K, Harrison B, Akimoto S, Sarker MR, McClane BA (2005) Association of beta2 toxin production with Clostridium perfringens type A human gastrointestinal disease isolates carrying a plasmid enterotoxin gene. Mol Microbiol 56(3):747-762

França M, Barrios MA, Stabler L, Zavala G, Shivaprasad HL, Lee MD, Villegas AM, Uzal FA (2016) Association of Beta2-positive Clostridium perfringens Type A with focal duodenal necrosis in egg-laying chickens in the United States. Avian Dis 60(1):43-49

Gao X, Yang Q, Huang X, Yan Z, Zhang S, Luo R, Wang P, Wang W, Xie K, Jiang T, Gun S (2020) Effects of Clostridium perfringens beta 2 toxin on apoptosis, inflammation, and barrier function of intestinal porcine epithelial cells. Microb Pathog 147:104379. https://doi.org/10.1016/j.micpath.2020.104379

Gao X, Huang X, Yang Q, Zhang S, Yan Z, Luo R, Wang P, Wang W, Xie K, Gun S (2021a) MicroRNA-21-5p targets PDCD4 to modulate apoptosis and inflammatory response to Clostridium perfringens beta2 toxin infection in IPEC-J2 cells. Dev Comp Immunol 114:103849. https://doi.org/10.1016/j.dci.2020.103849

Gao X, Yang Q, Zhang S, Huang X, Yan Z, Wang P, Luo R, Wang W, Xie K, Gun S (2021b) Epigenetic upregulation of ssc-miR-124a following treatment with Clostridium perfringens beta2-toxin attenuates both apoptosis and inflammation in intestinal porcine epithelial cells. Arch Biochem Biophys 701:108806. https://doi. org/10.1016/j.abb.2021.108806

Garmory HS, Chanter N, French NP, Bueschel D, Songer JG, Titball RW (2000) Occurrence of Clostridium perfringens beta2-toxin amongst animals, determined using genotyping and subtyping PCR assays. Epidemiol Infect 124(1):61-67 
Gibert M, Jolivet-Reynaud C, Popoff MR (1997) Beta2 toxin, a novel toxin produced by Clostridium perfringens. Gene 203(1):65-73. https://doi.org/10.1016/s0378-1119(97)00493-9

Gohari IM, Arroyo L, Macinnes JI, Timoney JF, Parreira VR, Prescott JF (2014) Characterization of Clostridium perfringens in the feces of adult horses and foals with acute enterocolitis. Can J Vet Res 78(1):1-7

Goldstein MR, Kruth SA, Bersenas AM, Holowaychuk MK, Weese JS (2012) Detection and characterization of Clostridium perfringens in the feces of healthy and diarrheic dogs. Can J Vet Res 76(3):161-165

Gurjar AA, Yennawar NH, Yennawar HP, Rajashankar KR, Hegde NV, Jayarao BM (2007) Expression, crystallization and preliminary $\mathrm{X}$-ray diffraction studies of recombinant Clostridium perfringens beta 2-toxin. Acta Crystallogr Sect F Struct Biol Cryst Commun 63(Pt 6):484-487

Gurjar A, Li J, McClane BA (2010) Characterization of toxin plasmids in Clostridium perfringens type C isolates. Infect Immun 78(11):4860-4869

Gurtner C, Popescu F, Wyder M, Sutter E, Zeeh F, Frey J, von Schubert C, Posthaus H (2010) Rapid cytopathic effects of Clostridium perfringens beta-toxin on porcine endothelial cells. Infect Immun 78(7):2966-2973

Harrison B, Raju D, Garmory HS, Brett MM, Titball RW, Sarker MR (2005) Molecular characterization of Clostridium perfringens isolates from humans with sporadic diarrhea: evidence for transcriptional regulation of the beta2-toxin-encoding gene. Appl Environ Microbiol 71(12):8362-8370

Hazlett MJ, Kircanski J, Slavic D, Prescott JF (2011) Beta 2 toxigenic Clostridium perfringens type A colitis in a three-day-old foal. J Vet Diagn Invest 23(2):373-376

Herholz C, Miserez R, Nicolet J, Frey J, Popoff M, Gibert M, Gerber H, Straub R (1999) Prevalence of beta2-toxigenic Clostridium perfringens in horses with intestinal disorders. J Clin Microbiol 37(2):358-361

Iacovache I, De Carlo S, Cirauqui N, Dal Peraro M, van der Goot FG, Zuber B (2016) Cryo-EM structure of aerolysin variants reveals a novel protein fold and the pore-formation process. Nat Commun $7: 12062$

Jiang J, Pentelute BL, Collier RJ, Zhou ZH (2015) Atomic structure of anthrax protective antigen pore elucidates toxin translocation. Nature 521(7553):545-549

Jost BH, Billington SJ, Trinh HT, Bueschel DM, Songer JG (2005) Atypical cpb2 genes, encoding beta2-toxin in Clostridium perfringens isolates of nonporcine origin. Infect Immun 73(1):652-656

Kitadokoro K, Nishimura K, Kamitani S, Fukui-Miyazaki A, Toshima H, Abe H, Kamata Y, Sugita-Konishi Y, Yamamoto S, Karatani H, Horiguchi Y (2011) Crystal structure of Clostridium perfringens enterotoxin displays features of beta-pore-forming toxins. J Biol Chem 286(22):19549-19555

Knapp O, Maier E, Mkaddem SB, Benz R, Bens M, Chenal A, Geny B, Vandewalle A, Popoff MR (2010) Clostridium septicum alpha-toxin forms pores and induces rapid cell necrosis. Toxicon 55(1):61-72

Knapp O, Benz R, Popoff MR (2016) Pore-forming activity of clostridial binary toxins. Biochim Biophys Acta 1858(3):512-525

Konus M, Koy C, Mikkat S, Kreutzer M, Zimmermann R, Iscan M, Glocker MO (2013) Molecular adaptations of Helicoverpa armigera midgut tissue under pyrethroid insecticide stress characterized by differential proteome analysis and enzyme activity assays. Comp Biochem Physiol Part D Genomics Proteomics 8(2):152-162

Kumar S, Stecher G, Tamura K (2016) MEGA7: molecular evolutionary genetics analysis version 7.0 for bigger datasets. Mol Biol Evol 33(7):1870-1874
Kumar VV, James BL, Ruß M, Mikkat S, Suresh A, Kämmerer PW, Glocker MO (2018) Proteome analysis reveals that de novo regenerated mucosa over fibula flap-reconstructed mandibles resembles mature keratinized oral mucosa. Oral Oncol 78:207-215

Laemmli UK (1970) Cleavage of structural proteins during the assembly of the head of bacteriophages T4. Nature (london) 227:680-685

Lebrun M, Filée P, Mousset B, Desmecht D, Galleni M, Mainil JG, Linden A (2007) The expression of Clostridium perfringens consensus beta2 toxin is associated with bovine enterotoxaemia syndrome. Vet Microbiol 120(1-2):151-157

Luo R, Yang Q, Huang X, Yan Z, Gao X, Wang W, Xie K, Wang $\mathrm{P}$, Gun S (2020a) Clostridium perfringens beta2 toxin induced in vitro oxidative damage and its toxic assessment in porcine small intestinal epithelial cell lines. Gene 759:144999. https://doi.org/ 10.1016/j.gene.2020.144999

Luo R, Yan Z, Yang Q, Huang X, Gao X, Wang P, Wang W, Xie K, Gun S (2020b) Inhibition of ssc-microRNA-140-5p ameliorates the Clostridium perfringens beta 2 toxin-induced inflammatory response in IPEC-J2 cells via the ERK1/2 and JNK pathways by targeting VEGFA. Mol Immunol 127:12-20. https://doi.org/10. 1016/j.molimm.2020.1008.1017

Manteca C, Daube G, Jauniaux T, Linden A, Pirson V, Detilleux J, Ginter A, Coppe P, Kaeckenbeeck A, Mainil JG (2002) A role for the Clostridium perfringens beta2 toxin in bovine enterotoxaemia? Vet Microbiol 86(3):191-202

Nelson AP, McQuarrie DA (1975) The effect of discrete charges on the electrical properties of a membrane. I. J Theor Biol 55(1):13-27

Park M, Rafii F (2019) The prevalence of plasmid-coded cpe enterotoxin, $\beta_{2}$ toxin, tpeL toxin, and tetracycline resistance in Clostridium perfringens strains isolated from different sources. Anaerobe 56:124-129

Petit L, Maier E, Gibert M, Popoff MR, Benz R (2001) Clostridium perfringens epsilon toxin induces a rapid change of cell membrane permeability to ions and forms channels in artificial lipid bilayers. J Biol Chem 276(19):15736-15740

Petit L, Gibert M, Gourch A, Bens M, Vandewalle A, Popoff MR (2003) Clostridium perfringens epsilon toxin rapidly decreases membrane barrier permeability of polarized MDCK cells. Cell Microbiol 5(3):155-164

Popescu F, Wyder M, Gurtner C, Frey J, Cooke RA, Greenhill AR, Posthaus H (2011) Susceptibility of primary human endothelial cells to C. perfringens beta-toxin suggesting similar pathogenesis in human and porcine necrotizing enteritis. Vet Microbiol 153(1-2):173-177

Popoff MR (2011) Epsilon toxin: a fascinating pore-forming toxin. Febs J 278:4602-4615

Popoff MR (2014) Clostridial pore-forming toxins: powerful virulence factors. Anaerobe 30:220-238

Postu PA, Ion L, Drochioiu G, Petre BA, Glocker MO (2019) Electrophoresis Mass spectrometric characterization of the zein protein composition in maize flour extracts upon protein separation by SDS-PAGE and 2D gel electrophoresis. Electrophoresis 40(20):2747-2758

Rood JI, Adams V, Lacey J, Lyras D, McClane BA, Melville SB, Moore RJ, Popoff MR, Sarker MR, Songer JG, Uzal FA, Van Immerseel F (2018) Expansion of the Clostridium perfringens toxin-based typing scheme. Anaerobe 53:5-10

Röwer C, Vissers JP, Koy C, Kipping M, Hecker M, Reimer T, Gerber B, Thiesen HJ, Glocker MO (2009) Towards a proteome signature for invasive ductal breast carcinoma derived from label-free nanoscale LC-MS protein expression profiling of tumorous and glandular tissue. Anal Bioanal Chem 395(8):2443-2456

Röwer C, George C, Reimer T, Stengel B, Radtke A, Gerber B, Glocker MO (2018) Distinct Ezrin truncations differentiate metastases in sentinel lymph nodes from unaffected lymph node tissues, from 
primary breast tumors, and from healthy glandular breast tissues. Transl Oncol 11(1):1-10

Savva CG, Clark AR, Naylor CE, Popoff MR, Moss DS, Basak AK, Titball RW, Bokori-Brown M (2019) The pore structure of Clostridium perfringens epsilon toxin. Nat Commun 10(1):2641

Schleberger C, Hochmann H, Barth H, Aktories K, Schulz GE (2006) Structure and action of the binary $\mathrm{C} 2$ toxin from Clostridium botulinum. J Mol Biol 364(4):705-715

Schmid A, Benz R, Just I, Aktories K (1994) Interaction of Clostridium botulinum $\mathrm{C} 2$ toxin with lipid bilayer membranes. Formation of cation-selective channels and inhibition of channel function by chloroquine. J Biol Chem 269(24):16706-16711

Schotte U, Truyen U, Neubauer H (2004) Significance of beta 2-toxigenic Clostridium perfringens infections in animals and their predisposing factors-a review. J Vet Med B Infect Dis Vet Public Health 51(10):423-426

Shatursky O, Bayles R, Rogers M, Jost BH, Songer JG, Tweten RK (2000) Clostridium perfringens beta-toxin forms potentialdependent, cation-selective channels in lipid bilayers. Infect Immun 68(10):5546-5551

Sinz A, Bantscheff M, Mikkat S, Ringel B, Drynda S, Kekow J, Thiesen HJ, Glocker MO (2002) Mass spectrometric proteome analyses of synovial fluids and plasmas from patients suffering from rheumatoid arthritis and comparison to reactive arthritis or osteoarthritis. Electrophoresis 23(19):3445-3456

Song L, Hobaugh MR, Shustak C, Cheley S, Bayley H, Gouaux JE (1996) Structure of staphylococcal alpha-hemolysin, a heptameric transmembrane pore. Science 274:1859-1866
Songer JG (2010) Clostridia as agents of zoonotic disease. Vet Microbiol 140(3-4):399-404

Trias J, Benz R (1993) Characterization of the channel formed by the mycobacterial porin in lipid bilayer membranes. Demonstration of voltage gating and of negative point charges at the channel mouth. J Biol Chem 268:6234-6240

Uzal FA, Vidal JE, McClane BA, Gurjar AA (2010) Clostridium perfringens toxins involved in mammalian veterinary diseases. Open Toxinol J 2:24-42

van Asten AJ, Nikolaou GN, Gröne A (2010) The occurrence of cpb2toxigenic Clostridium perfringens and the possible role of the beta2-toxin in enteric disease of domestic animals, wild animals and humans. Vet J 183(2):135-140

Vilei EM, Schlatter Y, Perreten V, Straub R, Popoff MR, Gibert M, Gröne A, Frey J (2005) Antibiotic-induced expression of a cryptic $\mathrm{cpb} 2$ gene in equine beta2-toxigenic Clostridium perfringens. Mol Microbiol 57(6):1570-1581

Waters M, Savoie A, Garmory HS, Bueschel D, Popoff MR, Songer JG, Titball RW, McClane BA, Sarker MR (2003) Genotyping and phenotyping of beta2-toxigenic Clostridium perfringens fecal isolates associated with gastrointestinal diseases in piglets. J Clin Microbiol 41(8):3584-3591

Publisher's Note Springer Nature remains neutral with regard to jurisdictional claims in published maps and institutional affiliations. 